\title{
L'occhio immobile di Quad che ferma il mondo
}

\author{
Alessandra Cirafici \\ Carlos Campos
}

Abstract

Quad è una 'lirica visiva' composta e messa in scena per la televisione da Samuel Beckett nel 198।. Un'opera di straordinario ermetismo che racconta, come ci dice Deleuze di un gruppo di quattro 'esausti' personaggi e del loro moto ordinato attraverso cui 'esauriscono' tutto lo spazio a loro disposizione, percorrendone la distanza nell'unico modo a loro concesso, evitando con cura di 'toccarsi'. Liberata totalmente dalla parola, l'opera si presenta come 'ritornello essenzialmente motorio', gesto del corpo che disegna il proprio percorso nello spazio del quadrato e in questo gesto visivamente lo genera, gli conferisce un senso e al tempo stesso lo esaurisce. A partire dalla lettura del 'testo' di Beckett e dalla sua declinazione visiva in alcune sperimentazioni attuate in contesti accademici, il saggio si lascia sedurre dalla potente metafora che sembra legare l'opera di Beckett alla attuale condizione esistenziale e ne propone una lettura in cui i concetti di linguaggio (e per esso linguaggio del corpo e traiettoria nello spazio/tempo), distanza (e per esso misura ad quadratum la cui potenzialità è nel centro) e tecnologia (nel senso pieno di technè e dunque di dispositivo spazio/temporale che dialoga oggi con la dimensione digitale) articolano una narrazione di imponderabile potenza in cui la messa in scena dell'opera di Beckett, nel suo tempo e nel tempo a venire, si declina oggi nella metafora della condizione esistenziale che il 'distanziamento' fisico ed emotivo ci costringe a sperimentare.

Parole chiave

Beckett, Quad, performance, L'esausto, rappresentazione.

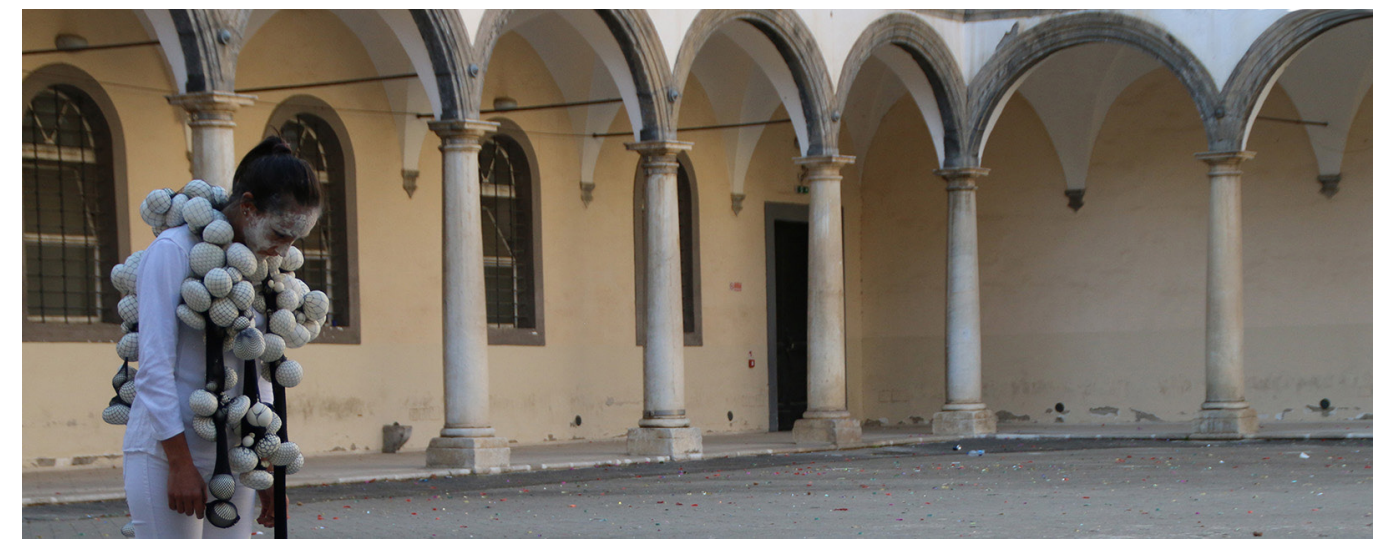




\section{Quad I+II_Pezzo per quattro attori, luci e percussioni_Evitando il centro}

"Quad, senza parole, senza voci, è un quadrilatero, un quadrato. Eppure, è perfettamente determinato, ha quelle certe dimensioni, ma le sue uniche determinazioni sono le singolarità formali, vertici equidistanti e centro, i soli contenuti o occupanti sono i quattro personaggi uguali che lo percorrono ininterrottamente [...] Sono personaggi affetti da nulla in uno spazio che non può essere affetto da nulla."

[Deleuze|992, p. 31]

Quattro performer dal sesso indefinito, incappucciati in insoliti mantelli bianchi, si aggirano con fare inquieto negli ambulacri del chiostro di San Lorenzo ad Septimum, come sempre pieno di studenti e docenti del Dipartimento di Architettura e Design, ignari di quanto sta per avvenire. Aspettano che smetta di piovere per entrare in scena. Per giorni hanno provato le andature e i ritmi insieme ai quattro percussionisti che li accompagneranno, mentre colleghi laboriosi 'tessevano' materiali inusuali (fascette di plastica, dischetti in cotone, gomma, nylon...) per cucire gli abiti di scena. Sono tutti studenti del Corso di studi in Design per la Moda e a guidarli in questa straordinaria esperienza è un gruppo di docenti visionario, entusiasta e un po' spericolato! [ I ]. Tutto è pronto e finalmente la pioggia si è fermata. Un intenso ritmo di percussioni invade il chiostro: è il segnale. La performance può iniziare. Molti dagli ambulacri si affacciano per guardare quel che accade lì, al centro del chiostro. II dispositivo spaziale, come nell'originale prestigioso di cui la performance è una libera, ma fedele interpretazione, prevede che i quattro performer - "né identici, né del tutto diversi, ma analoghi" [Cascetta 2000] - con passi cadenzati e precisi, in perfetto sincrono entrino nel quadrato, uno alla volta e, a un tratto, dal quadrato, uno alla volta escano, per fermarsi nei vertici. Quando nel loro incedere incessante si trovano a condividere lo spazio, sono obbligati a riprodurre i movimenti uno dell'altro in forma speculare [2]. Al ritmo delle percussioni che li accompagnano i performer con i loro passi tracciano il quadrato, della cui configurazione geometrica è chiaramente visibile un elemento: il centro. La performance riempie il chiostro, ne ferma il consueto vociare e lo sostituisce con il ritmo cadenzato e ossessivo delle percussioni, con il suo ipnotico movimento reiterato che scivola sul pavimento ancora bagnato e lucido per la pioggia. Pochi minuti, ma di intensa poesia ... e poi un grande applauso! Dietro

Fig. I. Quad 2017. Aversa. Chiostro di San Lorenzo. DADI Universita Vanvitelli. Allestimento e messa in scena: Direzione generale: Carlos Campos.
Coreografica:Yamila Zynda Aiub. Musica: Carlos Campos. Costumi elaborati nell'ambito elaborati nellambito Carlos Campos Carlos Campos Visiting professor a.a.2017/18. Corso di Studi in Design per la moda, Corso di Fondamenti visivi del progetto (prof. A. Cirafici). Attori, costumi e musica allievi del DAD: Luigi Balsamo, Nunzia Buonpane, Giovanna Cinque, Pasquale Conte, Sara Coscione, Laura Di Dar Raffaele La Marca, Amelia Raffaele La Marca, Amelia Lauro, Filomena Passante Maria Antonietta Ran Mara Serra, Fabrizio Santo.
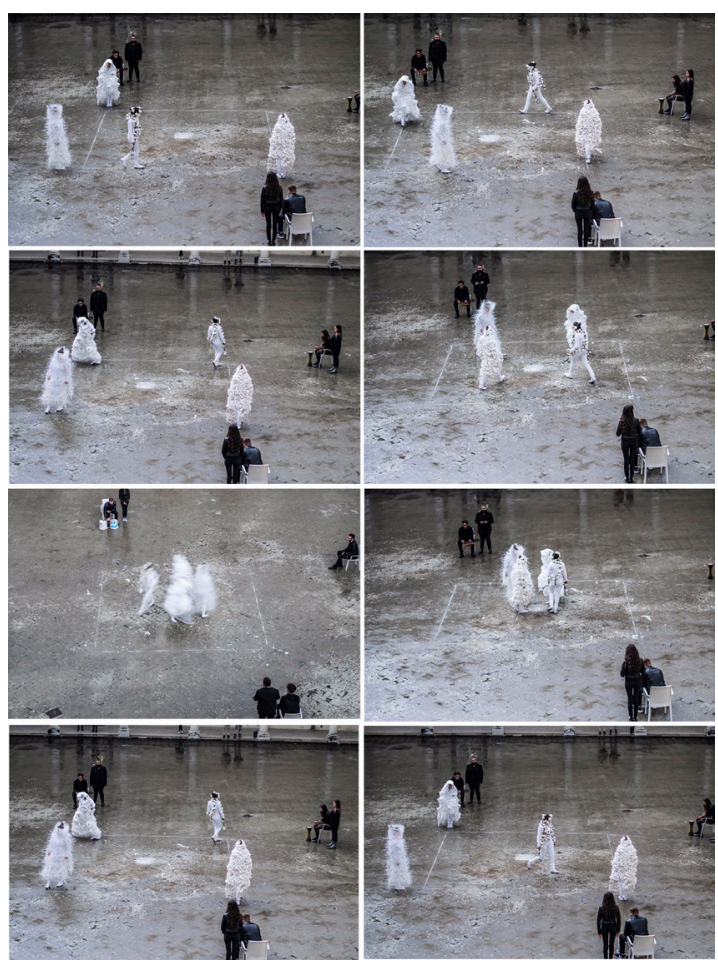
questa misteriosa performance, c'è Samuel Beckett e quella che lui stesso ebbe a definire come una "follia televisiva", pensata per la scuola di danza di Stoccarda. Trasmessa per la prima volta da un'emittente tedesca l'8 ottobre 198I, con il titolo di Quad resta una delle sue opere più ermetiche e inquietanti, che a quaranta anni dalla sua messa in onda, continua a lasciarsi attraversare da universi interpretativi che ne amplificano significati simbolici e generano metafore potenti Piccola architettura visiva, dispositivo scenico, nel senso più ampio che al termine 'dispositivo' Michel Faucault [3] ci ha insegnato ad attribuire, Quad è un'opera totalmente priva dell'elemento verbale a cui ha completamente abdicato in favore di un linguaggio che sottolinea fortemente l'aspetto della visione e ne radicalizza la scelta [4]. Una 'lirica visiva' che per comunicarci la sua poesia non può che essere realizzata nell'unico modo previsto dal suo autore. I tredici minuti della performance originale i sviluppano come la messa in scena di un 'codice' e difatti il testo predisposto da Beckett si configura esattamente come una sequenza alfanumerica, come un calcolo combinatorio finalizzato a esaurire tutte le combinazioni possibili di una condizione spazio/temporale predefinita. Quad è essenzialmente un 'ritornello motorio': "la serie è dotata di un ordine seguendo il quale cresce e decresce, ricresce e ri-decresce [...] è un canone" [Deleuze 20 I0, p. 32]. II quadrato di fatto non esiste se non nella traiettoria generata dai corpi in movimento che ne tracciano i lati e sperimentano, nella lunghezza dei passi, l'incommensurabilità della diagonale, ne scandiscono i vertici. I corpi percorrono dunque incessantemente una distanza e, nel percorrerla, 'esauriscono' lo spazio che la contiene. II testo di Beckett in questo è chiaro: si tratta di esaurire lo spazio! La potenza è nel centro dove si incrociano le diagonali, luogo di attrazione del movimento e al tempo stesso luogo da evitare. È il luogo dove potenzialmente i corpi sarebbero costretti a incontrarsi, scontrarsi, entrare in contatto, ma nel movimento stabilito per la sequenza questa possibilità svanisce, trova una soluzione, una negoziazione possibile. A nessun danzatore è permesso di sfiorare il centro. La soluzione è in un "leggero stacco centrale, quel colpo d'anca, quello scarto, quello iato, quella scansione, quella sincope che prevede lo scontro e lo scongiura" [Deleuze 2010, p. 33].
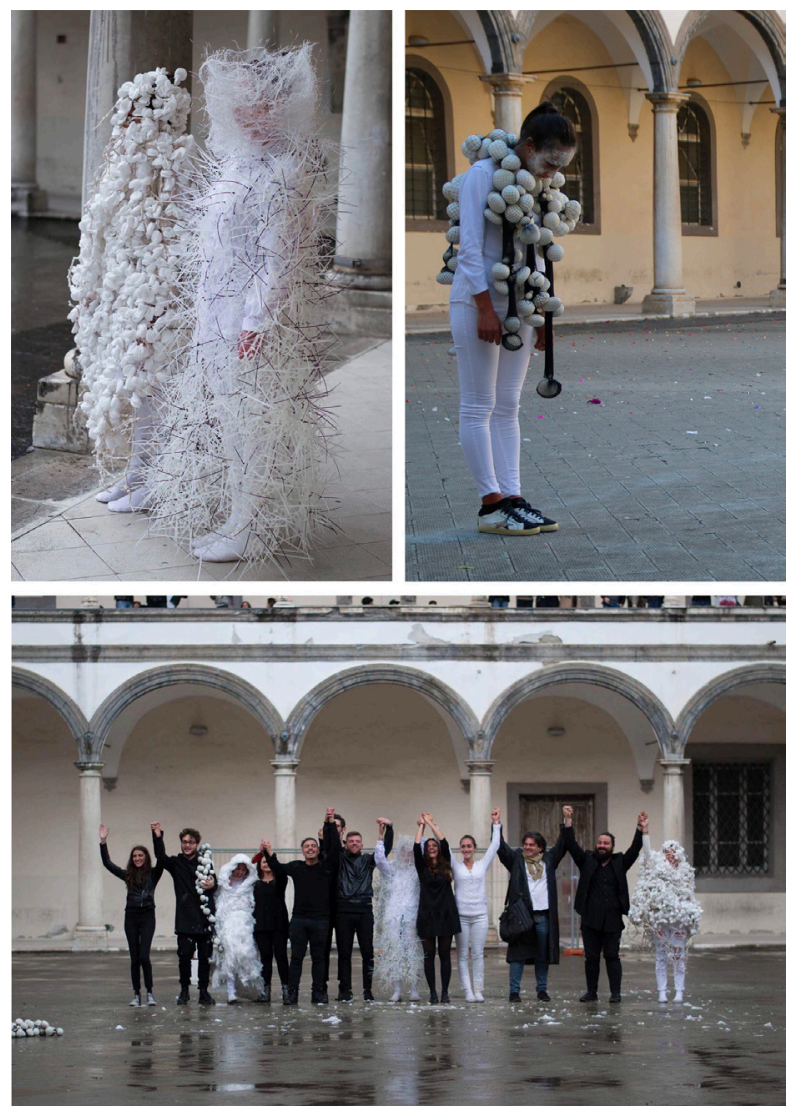
I corpi si evitano ed in quell'evitarsi, verrebbe da dire, è la loro sola possibilità di sopravvivenza. Solo così alle serie è consentito di continuare ed esaurire tutte le combinazioni possibili. Potente e ignara metafora della condizione contemporanea che rimodella non solo le nostre abitudini, ma il nostro ambiente e lo fa proponendo la "creazione di bolle esistenziali - spesso in forma di cellule ristrette - in cui confiniamo il nostro raggio di azione in cui tuttavia ci sembra di poter essere al sicuro" [5], in una condizione che ci costringe a rinegoziare il rapporto prossemico con l'altro, di cui rifuggiamo il contatto. C'è di più. Nel descrivere la condizione dei personaggi di Quad, Deleuze introduce l'immagine dell'esausto', facendo ben attenzione a non confonderlo con quella dello stanco. L'esausto è molto più dello stanco: "lo stanco ha esaurito solo la messa in atto, mentre l'esausto esaurisce tutto il possibile. Lo stanco non può più realizzare, ma l'esausto non può più possibilizzare" [Deleuze 20 I0, p. 9]. E probabilmente quella di 'esausti' è la condizione esistenziale più prossima a quanto stiamo vivendo in questo nostro inimmaginabile tempo presente, nel nostro incessante esaurire non solo lo spazio limitato che ci è concesso di abitare, ma anche le possibilità di quello spazio mentale che ci

Fig. 3. Quad 2008, 7 LId'A - Laboratorio Internazionale d'Architettura, Direzione Scientifica: Laura Thermes. Workshop curato da Carlos Campos a Reggio Calabria e Messina: ! caratteri dello spazio pubblico. Attori del pubblico.Attoridel Nicolini Per l'occasione Nicolini. Per loccasione vennero allestite due rappresentazioni, una a Reggio Calabria e una Messina per enfatizzare l'idea della 'distanza' tra le due coste dello Stretto.

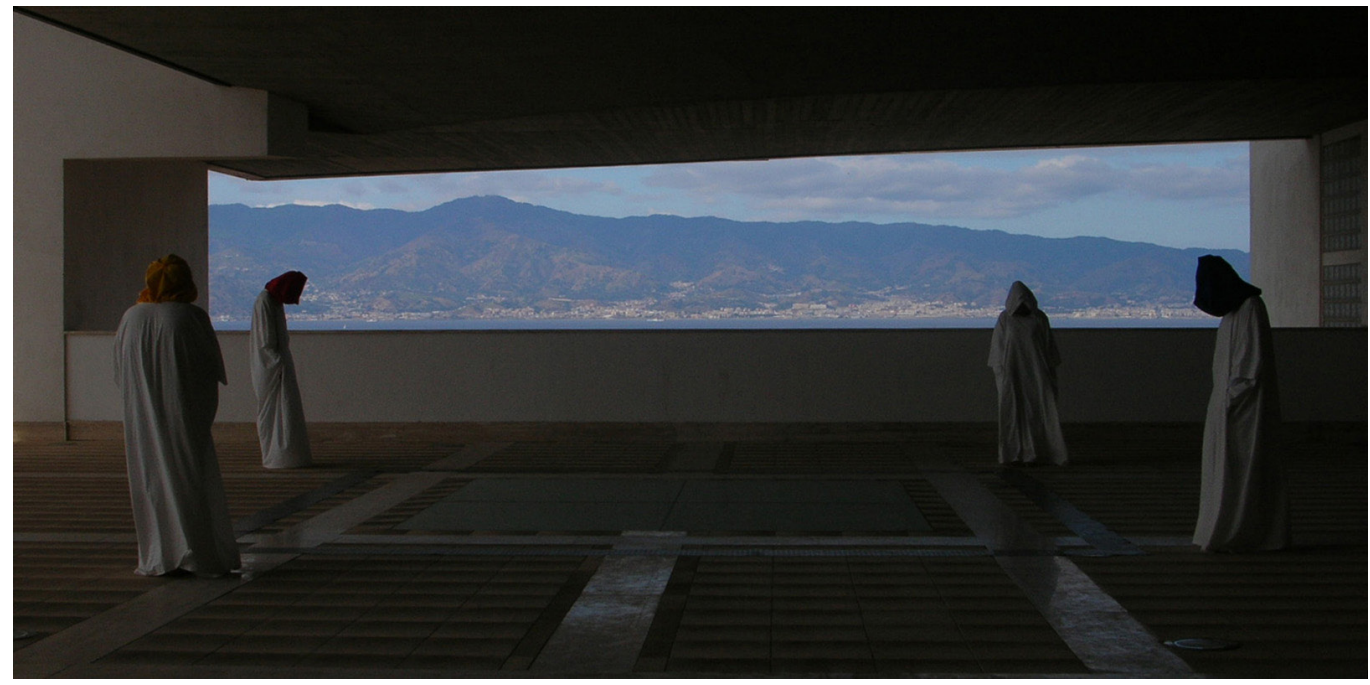

sembra di perdere a ogni nuova privazione, a ogni nuovo limite imposto a ogni nuovo confinamento mentale oltre che fisico, che quotidianamente sperimentiamo. Ma non è solo per questa potente suggestione interpretativa che è interessante per noi, oggi, guardare a Quad come fonte di ispirazione. Quad ci spinge a riflettere sulle modalità di ri-mediazione di linguaggi visivi, se per remediation intendiamo il fortunato neologismo coniato da Bolter e Gru$\sin [6]$ che con esso intendono descrivere le nuove modalità di rapporto che caratterizzano la interrelazione tra i vari ambienti mediali, specie oggi in un panorama contraddistinto dalla presenza pervasiva dei media digitali. Quad è un'opera pensata da Beckett per la televisione, e il fatto non è marginale. Beckett, compie, infatti, un fondamentale atto di ri-mediazione del linguaggio teatrale nel nuovissimo ambiente mediale televisivo. Ne sperimenta i tempi ne stressa le potenzialità espressive con una meticolosa attitudine tesa a cogliere l'essenza del mezzo che usa, a basare l'espressione soprattutto - se non esclusivamente - su ciò che lo caratterizza "e quindi la sua scrittura come aveva privilegiato il suono nelle pièce radiofoniche, così privilegia l'immagine in quelle per la televisione" [Bertinetti 2002, p. XXVIII] giungendo ad abolire del tutto l'elemento verbale, facendo saltare ogni riferimento a ciò che normalmente associamo all'idea dramma televisivo. In Quad, la cinepresa è "alta e fissa, fuori dallo spazio chiuso e lavora continuamente" [Deleuze 20 I0, p. 37]. Si tratta di un unico piano sequenza, una visione a volo d'uccello degli attori in cui l'azione che si compie è sempre uguale a sé stessa. Importante lezione, quella di Beckett sulla necessità di riflettere sempre, ma oggi più che mai, sul processo continuo di ri-mediazione dei linguaggi e degli ambienti mediali. L'obbligo di distanziamento sociale, imposto negli ultimi mesi, ha sottoposto un gran 
Fig. 4. Quad 2008, 7 Lld’A - Laboratorio Internazionale di Architettura,

Direzione Scientifica: Laura Thermes. Workshop curato da Carlos Campos a Regrio Calabria a Reggio Calabria

dello spazio pubblico (foto di Francesco Tosetto). numero di pratiche sociali, culturali, lavorative ed educative a una ri-mediazione digitale che rende non più procrastinabile una riflessione sul rapporto che si è oggi venuta a instaurare tra i differenti media, sottolineando la loro forte e continua interrelazione in un panorama come quello contemporaneo, contraddistinto dalla presenza delle tecnologie digitali. La tensione tra la tendenza all'ubiquità dell'esperienza mediatica e la costruzione di nuove barriere diventa così una preoccupazione quotidiana che merita di essere indagata [7].

Aprire una riflessione su tali questioni richiede di affrontare congiuntamente l'indagine sulle tecniche, sui media e sulle forme della cultura visiva. In questo senso il processo di ri-mediazione indica, appunto, l'operazione ininterrotta di commento, di riproduzione e di sostituzione reciproca tra un medium e l'altro, attraverso cui il nuovo ingloba e trasforma il precedente. Si tratta di una condizione che, a guardare l'esperienza beckettiana è sempre esistita, ma che - hanno ben ragione Bolter e Grusin - assume oggi una diversa e maggiore ricorrenza e importanza. Si inserisce infatti in un orizzonte tecnologico totalmente inedito, in continua e rapida metamorfosi, al quale i mezzi di comunicazione preesistenti non possono che adattarsi avendo ben chiari i rischi connessi da un punto di vista stilistico ed estetico, e cioè quelli costituiti dal possibile dissolvimento delle specificità dei linguaggi mediali nella pluralità del mondo degli audiovisivi. (A.C.).

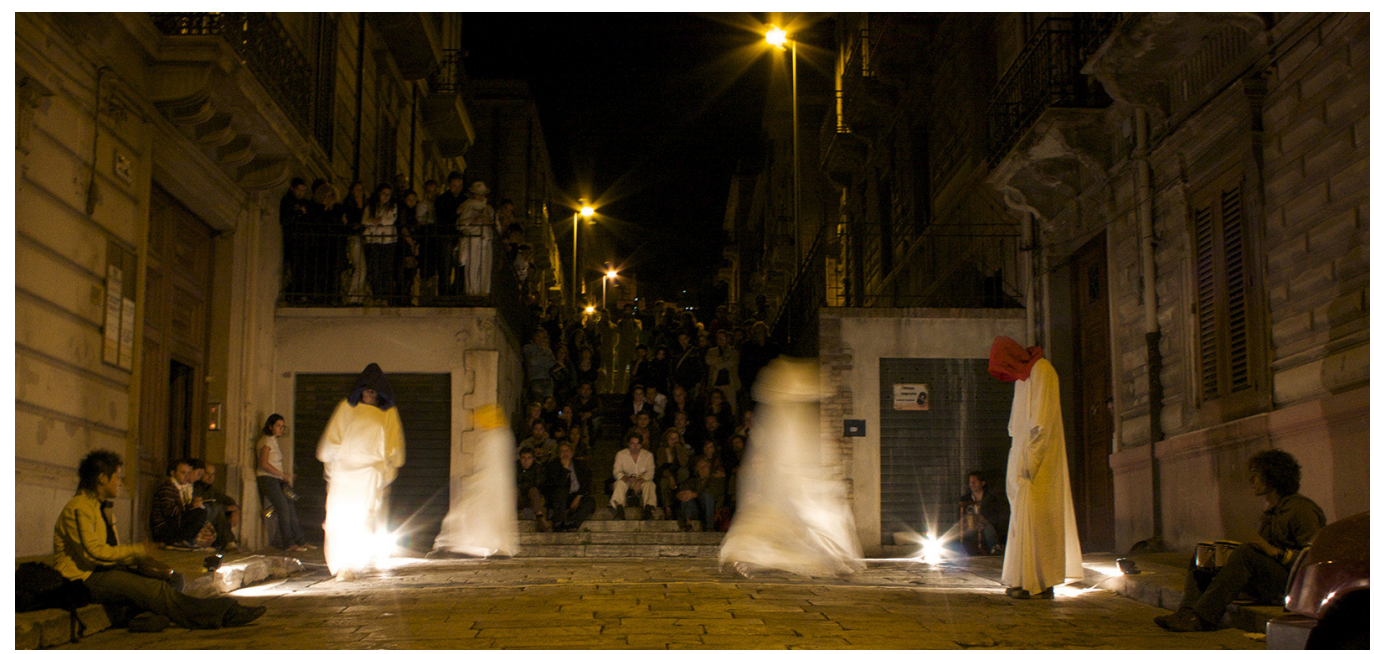

\section{Quad. Un'onda in riva al mare}

Quad è stato, originariamente, uno spettacolo creato per la televisione. E la televisione è un artefatto che emette unsimmagine da un punto fisso, da uno spazio dato, una stanza, almeno al tempo in cui Beckett pensava a Quad. Ciò significa che la rappresentazione originale dello spettacolo non ci mostra un gruppo di attori-danzatori che percorrono alternativamente le diagonali e i lati di un quadrato mentre quattro percussionisti suonano in modo sincrono, 'ma la sua trasmissione' (la sua riproduzione). Beckett usa l'immagine televisiva nello stesso modo in cui è stata usata la fotografia, estraendo un'immagine dal flusso dell'esperienza, fissandola e moltiplicandola allo stesso tempo. Questa azione, analoga alla fissazione dell'eterno flusso di coscienza in parole che non potranno mai rappresentare questo flusso, è la prima azione beckettiana in relazione al mezzo televisivo.

Le parole non possono afferrare la dinamica della produzione di significato nella coscienza. Così, le immagini televisive non saranno in grado di cogliere le diverse prospettive - e quindi le scale di approssimazione - in cui si svolge lo spettacolo dal vivo.

Queste diverse prospettive andranno perse, così come si perdono le associazioni, le riflessioni, i salti di livello e gli antagonismi che portano la coscienza alla deriva del suo flusso. Beckett vuole fissare questo flusso in opere come (W)horoscope, comprimendo il tempo, 
denunciando allo stesso tempo che questa azione è tanto impossibile quanto necessaria. In Quad, la telecamera statica, una visione a volo d'uccello degli attori, compie la stessa azione. Una volta che Beckett assume il mezzo che sarà oggetto della sua rappresentazione, decide di portarlo ai suoi limiti, a quei luoghi dove l'esperienza viene rinaturalizzata. In Quad non esiste un 'originale', o l'originale (sia il modello fotografico che i ballerini al momento di sviluppare le azioni), ha poca o quasi nessuna importanza. Così come la fotografia ha rivoluzionato il concetto di 'originale', nel senso di 'unico, irripetibile, univoco" che avevano la pittura, la monocopia o il dagherrotipo, Beckett usa la televisione per applicare lo stesso strumento concettuale al suo teatro. Quando i mezzi destinati a produrre lo 'sguardo' diventano meccanici, e inoltre, come nel caso della fotografia, illimitatamente riproducibili, il concetto di 'originalità' si dispiega, si indebolisce e svanisce. Non è più la pennellata del pittore fiammingo, che deve essere imitata dal falsario con infinita fatica e allenamento fino a dover trasformare profondamente il proprio essere, che dà autenticità all'opera. La fotografia (e ancor più la televisione), racchiude l'esperienza artistica o di vita in un'interfaccia che la collega al mondo in modo illimitato. Nel caso della fotografia, attraverso la riproducibilità seriale che, unita all'apparato di diffusione dei giornali, la colloca in tutto il mondo quasi contemporaneamente. La televisione è un prodotto di questo intreccio di media. II teatro beckettiano per la televisione è il risultato della comprensione di questa deformazione della percezione dell'agito a vantaggio di una sistematizzazione dell'immagine che non solo si appropria di tutti gli spazi, di tutti gli sguardi, ma che, inoltre, è incapace di fermarsi. Se oggi mettere qualcosa su internet significa rinunciare al controllo su quella cosa, negli anni ‘80 trasmettere qualcosa in televisione significava perdere il controllo sulla rappresentazione. Quad è in primo luogo, la rappresentazione televisiva di Quad. Solo dopo un compito di editing, e attraverso un'inquadratura particolare, Quad viene installato nel mondo. In questo senso, Quad non è un'opera, un concerto o un balletto, che può essere filmato nel momento della sua rappresentazione, e la cui registrazione evoca quel momento specifico. Quad funziona all'interno della complessità di un modo atemporale, sempre distaccato dalla propria rappresentazione, in vista della costituzione di uno spazio infinitamente riproducibile, infinitamente 'reale'. Ancorando il nostro sguardo su quello schermo senza darci alcuna possibilità di fuga, Beckett ci costringe a concentrarci su quel punto centrale, il punto E, il centro del conflitto e il motore del

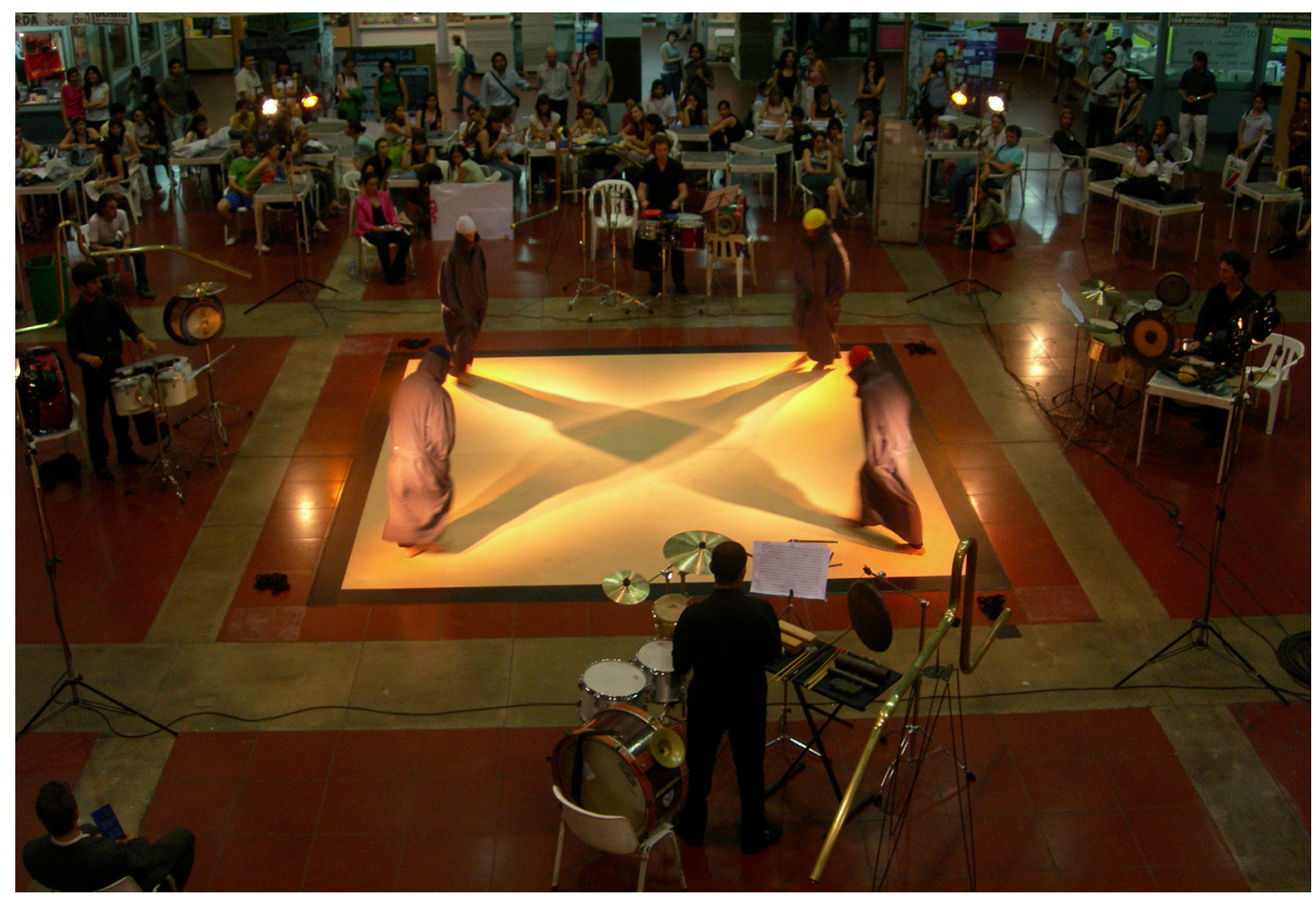


dramma dell'opera. Questo punto funge da occhio dello schermo. Da lì, progettato per un singolo occhio Quad ci guarda. Dal momento in cui il pavimento quadrato, i quattro attori e i loro percorsi diventano icone, esercitano la loro funzione, quella di produrre l'effetto di tenerci sotto il loro sguardo. Dalla sua disposizione sullo schermo, Quad nasconde e rivela, esibisce e separa le caratteristiche di una rappresentazione. (C.C.).

Fig. 6. Simulazione e Frattalizazzione di Quad. Carlos Campos, Yamila Zynda Aiub. Collaboratore: Martín Gromez L'immagine simula il processo attraverso in una sumulazione digitale, è possibile inserire piu 'attori' in scena: I quad, 4 quad, 16 quad Captures del video originale.

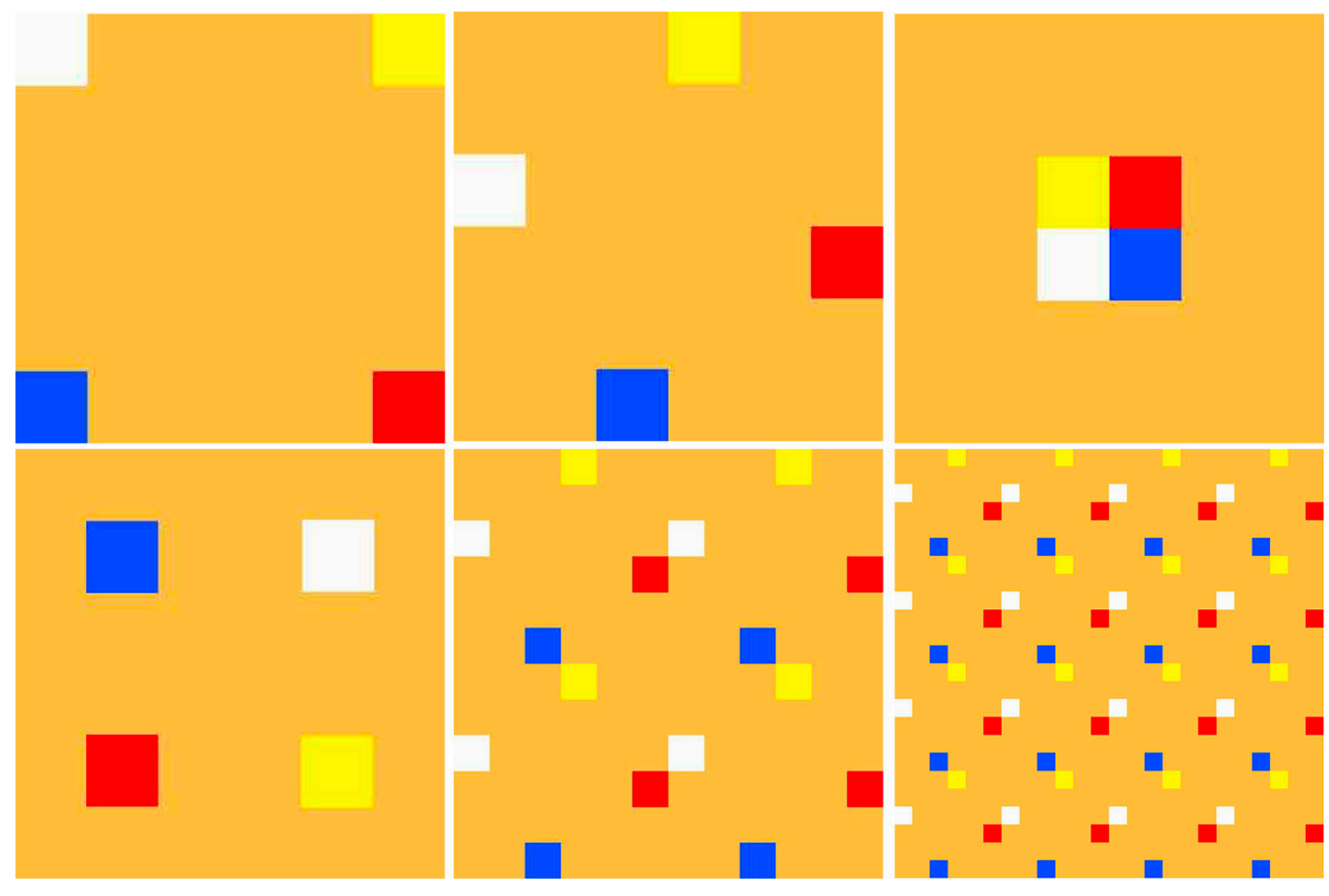

\section{Simulazione e frattalizzazione del Quad}

Originariamente proposto come meccanismo di prove per musicisti e ballerini, la simulazione è essa stessa un nuovo strumento. E Quad, al suo interno, comincia a esistere in un nuovo spazio senza precedenti: la frattalizzazione. La simulazione di

permette di percepire istantaneamente qualcosa per cui Beckett deve lavorare molto sulla scena: l'arrivo dei personaggi dal nulla, e la loro fuga nel nulla. Questo è così semplice nel mondo virtuale. La frattalizzazione permette di aumentare in progressione geometrica il numero di 'attori' al centro della rappresentazione, senza i problemi che, in una messa in scena con persone reali, lo renderebbero impossibile. Invece di assistere a una sola piéce con quattro attori che si muovono su di essa, possiamo mettere insieme quattro piéce, con sedici attori. $O$ sedici palchi, con sessantaquattro attori. E così via. Man mano che aumentiamo il numero di stadi e di attori, il movimento diminuisce la percezione della sua velocità originale, producendo un arresto virtuale della rappresentazione.

Per capire questo, immaginiamo un'altra situazione analoga. Pensiamo a un'onda, in riva al mare. Noi percepiamo il suo movimento dalla spiaggia come un mormorio ciclico, ripetitivo e costante. Come un insieme continuo di eventi discontinui. D'altra parte, se siamo dentro l'onda, come bagnanti, la percepiamo come una grande e fragorosa convulsione generale, in cui i suoni si mescolano, il movimento e l'evento dominano il nostro corpo, di cui perdiamo tutto il controllo.

Stando ora in cima a un burrone, percepiamo l'onda come un dolce ondeggiare che sussurra appena. Ma se fossimo invece allinterno di un aeroplano, vedremmo dal finestrino una quiete bianca e silenziosa. Così l'evento 'onda di rottura' non solo ha conformazioni multiple secondo il nostro punto di vista, ma da una distanza considerevole, il movimento avanti e 
indietro dell'onda si ferma letteralmente. Mentre assistiamo al progressivo aumento degli attori virtuali nella Simulazione frattale, assistiamo allo stesso tempo a diversi fenomeni di ordine estetico e poetico. Un effetto di 'distanziamento' o allontanamento dallo spazio in cui si svolge l'opera. Non solo perché i quadrati che sostituiscono gli attori che rappresentano lo spettacolo diventano più piccoli, ma anche perché l'attenzione precedentemente catturata da un unico gruppo di interpreti deve ora essere divisa in molti gruppi, introducendo diversi livelli di rilevamento del movimento, nuove generalità, collegamenti e particolarità. In secondo luogo, mantenendo, come è ovvio, la stessa cadenza temporale del lavoro (il fatto di avere più attori non significherebbe affatto che il lavoro debba essere eseguito più velocemente), la velocità relativa di ogni Quad deve necessariamente essere ridotta. Come in altre opere di Beckett, la sovrapposizione all'infinito del veicolo dell'espressione poetica (la parola, o nel caso di Quad, il movimento), produrrebbe un arresto di significato.

È necessario ripetere, più e più volte, ciò che non è possibile capire. Questa lezione è utile a noi designer oggi, come non lo è mai stata prima, perché oggi è il momento in cui il mondo è diventato quello che queste opere hanno anticipato. (C.C.).

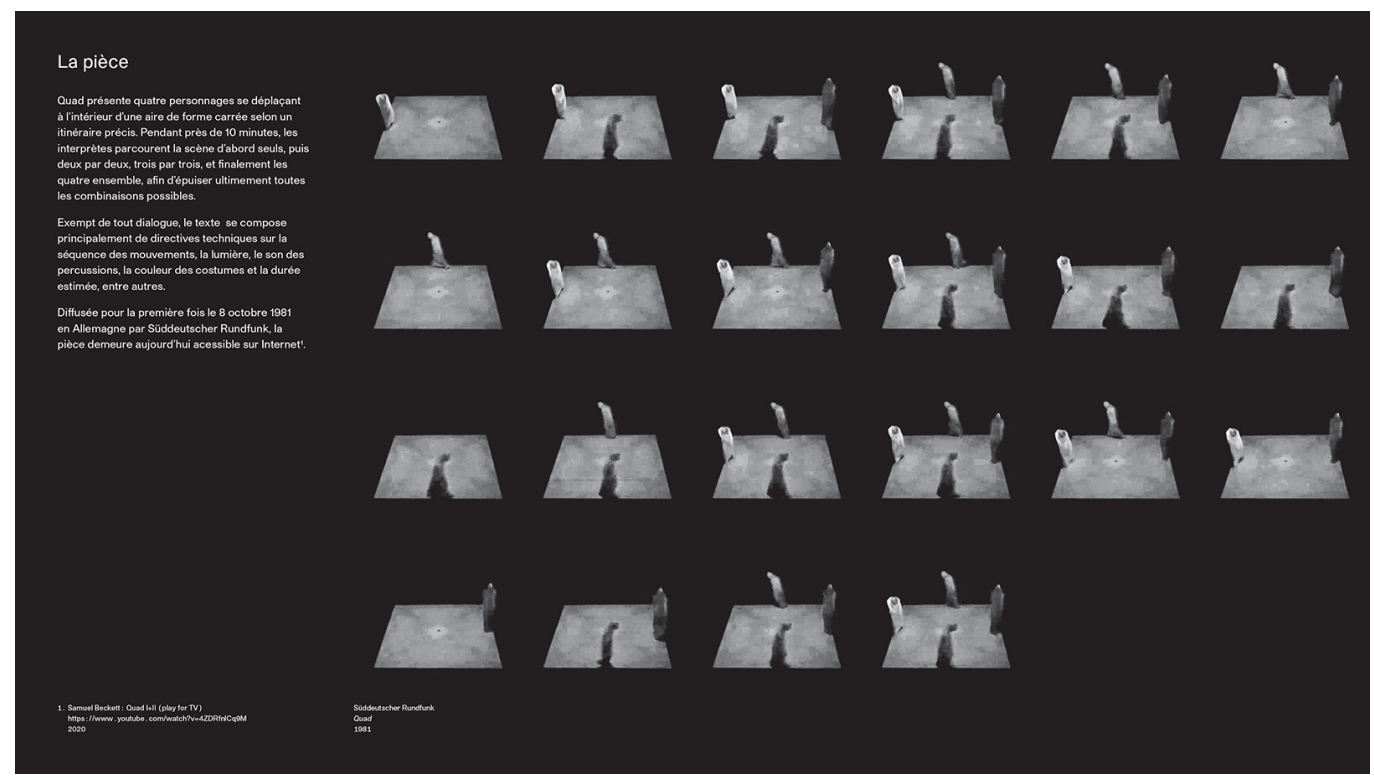

Note

[I] La performance è l'esito del workshop internazionale organizzato nell'ambito delle attività del Visiting Professor presso i) Dipartimento di Architettura e Disegno Industriale della Vanvitelli dal professor Carlos Campos docente presso I FADU dell'Università di Buenos Aires. Le attività, svolte in collaborazione con i docenti Alessandra Cirafici e Caterina Fiorentino furono dedicate agli studenti del Corso di Studi in Design per la Moda e riguardarono l'intero allestimento dello spettacolo, compresa la progettazione degli strumenti da percussione e la realizzazione dei tessuti per le tuniche. Gli allievi si esibirono nel Chiostro di San Lorenzo il 9 novembre 2017.

[2] Inizialmente, una figura attraversa il percorso, poi un'altra si unisce fino ad avere quattro figure in scena; poi, escono una a una man mano che ognuna termina il proprio schema, lasciando solamente una figura nello spazio. A poco a poco, tutte le possibili combinazioni di giocatori vengono presentate almeno una volta. Ogni figura descrive metà del quadrato, tracciando l'incommensurabilità del lato e della diagonale, facendo una svolta a scatti a sinistra per evitare il centro. Sembra che le figure si evitino reciprocamente, ma gradualmente ci si rende conto che stanno evitando il centro che rappresenta in qualche modo un oggetto spaziale vuoto.

[3] II riferimento è al concetto di 'dispositivo' espresso da Michel Faucault in Dits et écrits II, 1976- | 988. Sull'interpretazione del significato si veda anche Gilles Deleuze, 2007 e Giorgio Agamben, 2006.

[4] II copione originale prevedeva l'utilizzo di luci colorate che illuminassero e sottolineassero le diverse combinazioni di danzatori sul quadrato. Di fatto, la versione che andò in onda l'8 ottobre del 1981, per la regia dello stesso Beckett, risulta più essenziale e suggestiva. Fu presa inoltre un'importante decisione: far seguire alla ripresa originale a colori e con il suono delle percussioni una replica della ripresa stessa, ma in bianco e nero e con il solo suono dei passi (da qui il titolo 'alternativo' dell'opera: Quadrat I + II). Quando Beckett vide per la prima volta l'effetto delle due versioni affiancate esclamò: "Sembra che la seconda parte abbia luogo diecimila anni dopo la prima!". 
[5] Sul concetto di 'bolla' esistenziale legata alla condizione di ri-mediazione contemporanea del concetto di distanza si veda F. Casetti 2020.

[6] II riferimento è a Jay David Bolter, Richard Grusin, 2003.

[7] Al riguardo si veda Pinotti A., Somaini A. 2016.

\section{Riferimenti bibliografici}

Agamben G. (2006). Che cos'è un dispositivo?. Milano: Nottetempo.

Beckett S. (1982). Quad. Londra: Faber\&Faber [prima edizione italiana: Einaudi, 1985; prima messa in scena per la rete televisiva tedesca Suddeutscher Rundfunk, 8 Ottobre 1981].

Bertinetti P. (2002). (a cura di). Samuel Bekett. Teatro. Torino: Giulio Einaudi Editore.

Bolter J. D., Grusin R. (2003). Remediation. Competizione e integrazione tra media vecchi e nuovi. Milano: Guerini e Associati, Milano.

Cascetta A. M. (2000). Il tragico e l'umorismo. Studio sulla drammaturgia di Samuel Bekett. Firenze: Editoriale Le Lettere.

Casetti F. (2020). Close-up-ness. Masks, Screens, and Cellsl. In M.Treleani, F.Zucconi (a cura di). IMG journal, Issue 03 Remediating distances, pp. $106-119$.

Deleuze G. (2007). Che cos'è un dispositivo?. Napoli: Cronopio.

Deleuze G. (20 I0). L'esausto. Napoli: Edizione Cronopio (titolo originale L'epuisé. Paris: Les Edition del Minuit, 1992).

Pinotti A., Somaini A. (2016). Cultura visuale. Immagini, sguardi, media, dispositivi. Torino: Einaudi.

Autori

Alessandra Cirafici, Università degli Studi della della Campania “Luigi Vanvitelli”, alessandra.cirafici@unicampania.it Carlos Campos, Universidad de Buenos Aires, ccamposarq@gmail.com

Per citare questo capitolo: Cirafici Alessandra, Campos Carlos (2021). L'occhio immobile di Quad che ferma il mondo/Quad's motionless gaze that stops the world. In Arena A., Arena M., Mediati D., Raffa P. (a cura di). Connettere. Un disegno per annodare e tessere. Linguaggi Distanze Tecnologie. Atti del $42^{\circ}$ Convegno Internazionale dei Docenti delle Discipline della Rappresentazione/Connecting. Drawing for weaving relationship. Languages Distances Technologies. Proceedings of the $42^{\text {th }}$ International Conference of Representation Disciplines Teachers. Milano: FrancoAngeli, pp. I $507-1524$ 


\title{
Quad's Motionless Gaze that Stops the World
}

\author{
Alessandra Cirafici \\ Carlos Campos
}

Abstract

Quad is a 'visual lyric' composed and staged for television by Samuel Beckett in 1981. A work of extraordinary hermeticism, it tells, as Deleuze says, of a group of four 'exhausted' characters and their orderly movement through which they 'exhaust' all the space available to them, covering the distance in the only way allowed to them, carefully avoiding 'touching' each other. Totally free of words, the work appears as an 'essentially motor refrain', a gesture of the body that traces its own path through the space of the square and in this gesture visually generates it, gives it meaning and at the same time exhausts it. Starting from a reading of Beckett's 'text' and its visual declination in some experiments carried out in academic contexts, the essay lets itself be seduced by the powerful metaphor that seems to link Beckett's work to the current existential condition and proposes an interpretation in which the concepts of language (and for it body language and trajectory in space/time), distance (and for this reason misura ad quadratum whose potentiality is in the centre) and technology (in the full sense of technè and therefore of a space/time device that dialogues today with the digital dimension) articulate a narrative of imponderable power in which the staging of Beckett's work, in its time and in the time to come, is declined today in the metaphor of the existential condition that the physical and emotional 'distancing' forces us to experience.

Keywords

Beckett, Quad, performance, the exhausted, representation.

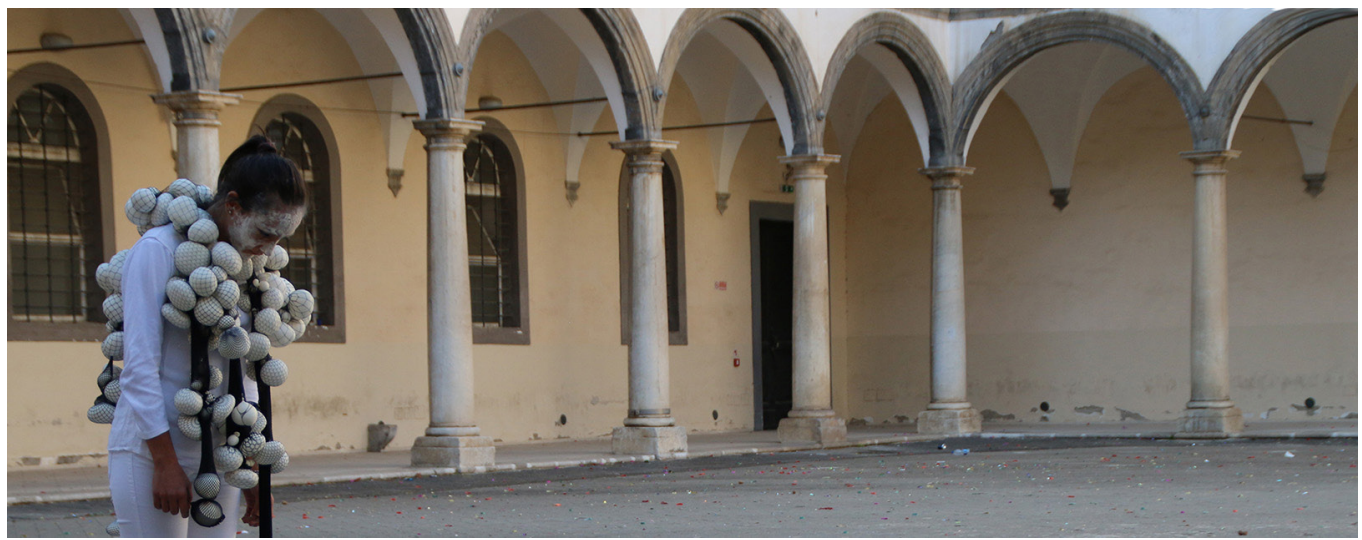




\title{
Quad I+II_piéce for four actors, lights and percussion_Avoiding the centre
}

\author{
"Quad, without words, without voices, is a quadrilateral, a square. \\ And yet, it is perfectly determined, it has those certain dimensions, \\ but its only determinations are the formal singularities, \\ equidistant vertices and centre, the only contents or occupants \\ are the four equal characters that run through it uninterruptedly $[\ldots]$ \\ They are characters affected by nothing in a space \\ that cannot be affected by anything." \\ [Deleuzel992, p. 31]
}

Four performers of indefinite gender, hooded in unusual white cloaks, wander restlessly in the cloisters of San Lorenzo ad Septimum, as always full of students and professors from the Department of Architecture and Design, unaware of what is about to happen. They are waiting for the rain to stop so they can go on stage. For days they have been rehearsing the gaits and rhythms with the four percussionists who will accompany them, while industrious colleagues have been 'weaving' unusual materials (plastic bands, cotton discs, rubber, nylon...) to sew the stage clothes. They are all students on the Fashion Design degree course and have been through this extraordinary experience by a visionary, enthusiastic and somewhat reckless group of teachers! [I] Everything is ready and the rain has finally stopped. An intense percussion rhythm invades the cloister: that's the signal. The performance can begin. Many from the ambulatories look out to see what is happening there, in the centre of the cloister. The spatial device, as in the prestigious original, of which the performance is a free but faithful interpretation, requires the four performers -"neither identical, nor completely different, but analogous" [Cascetta 2000] - with cadenced and precise steps, in perfect synchrony, to enter the square, one at a time, and suddenly to leave the square, one at a time, to stop at the vertexes. When, in their incessant striding, they find themselves sharing the space, they are obliged to reproduce each other's movements in mirror form [2]. To the rhythm of the accompanying percussion, the performers trace out the square with their steps, of whose geometric configuration one element is clearly visible: the centre. The performance fills the cloister, stops the usual chattering and replaces it with the cadenced and obsessive rhythm of the percussion, with its hypnotic repeated movement that slides on the floor still wet and shiny from the rain. A few minutes, but of intense poetry... and then a big round of

Fig. I. Quad 2017. Aversa. Cloister of University of Campania 'Luigi Vanvitelli'. Staging: Art Direction: Carlos Campos. Choreography: Yamila Zynda Aiub.

Music: Carlos Campos.

Costumes developed

in the framework

of the workshop of

prof. Carlos Campos,

Visiting professor

a.a.2017/18. Course of

Studies in Design for

fashion Course of Visua

fundamentals of the

project (prof. A. Cirafici)

Actors, costumes and

music DADI students:

Luigi Balsamo, Nunzia

Buonpane, Giovanna

Cinque, Pasquale Conte,

Sara Coscione, Laura

Sara Coscione, Lau

Mi Dio, Raffaele La

Filomena Passauro,

Fllomena Passante, Maria

Antonietta Ranieri, Mara

Serra, Fabrizio Santo.
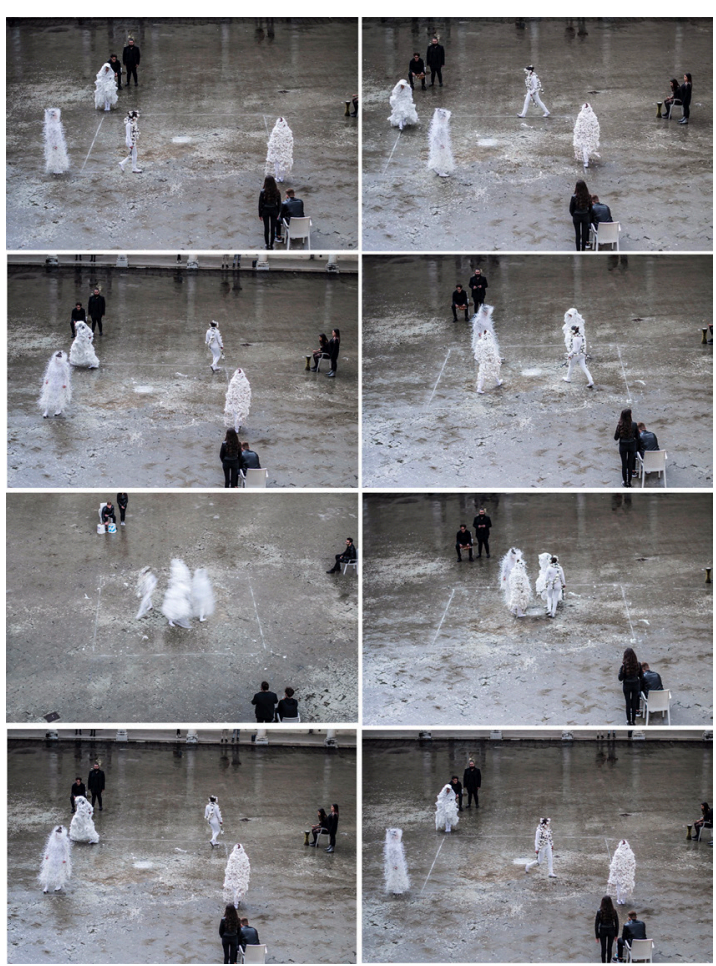
applause! Behind this mysterious performance, there is Samuel Beckett and what he himself defined as a 'television madness', conceived for the Stuttgart dance school. Broadcast for the first time by a German broadcaster on 8 October 1981, with the title Quad, it remains one of his most hermetic and disturbing works, which forty years after its original transmission continues to be crossed by universes of interpretation that amplify its symbolic meanings and generate powerful metaphors Small visual architecture, a scenic device, in the broadest sense that Michel Faucault [3] taught us to attribute to the term 'device', Quad is a work that is totally devoid of the verbal element, which it has been completely abdicated in favour of a language that strongly emphasises the aspect of vision and radicalizes its choice [4]. A visual lyric' that, in order to communicate its poetry, can be realized in the only way envisaged by its author. The thirteen minutes of the original performance are developed as the staging of a 'code', with the text prepared by Beckett being configured as an alphanumeric sequence, as a combinatory calculation aimed at exhausting all the possible combinations of a predefined space/time condition. Quad is essentially a 'motor refrain': "the series is endowed with an order following which it grows and decreases, regrows and re-decreases [...] it is a canon" [Deleuze 2010, p. 32]. The square does not in fact exist except in the trajectory generated by the bodies in movement that trace its sides and experience, in the length of their steps, the incommensurability of the diagonal, marking out its vertices. The bodies thus incessantly cover a distance and, in doing so, 'exhaust' the space that contains it. Beckett's text is clear in this: it is a question of exhausting space! The power is in the centre where the diagonals cross, a place of attraction of movement and at the same time a place to be avoided. It is the place where the bodies would potentially be forced to meet, to collide, to come into contact, but in the movement established for the sequence, the possibility of the clash vanishes, it finds a solution, a possible negotiation. No dancer is allowed to touch the centre. The solution lies in a "slight central detachment, that hip strike, that gap, that scan, that syncopation that foresees the clash and averts it" [Deleuze 20 I0, p. 33].
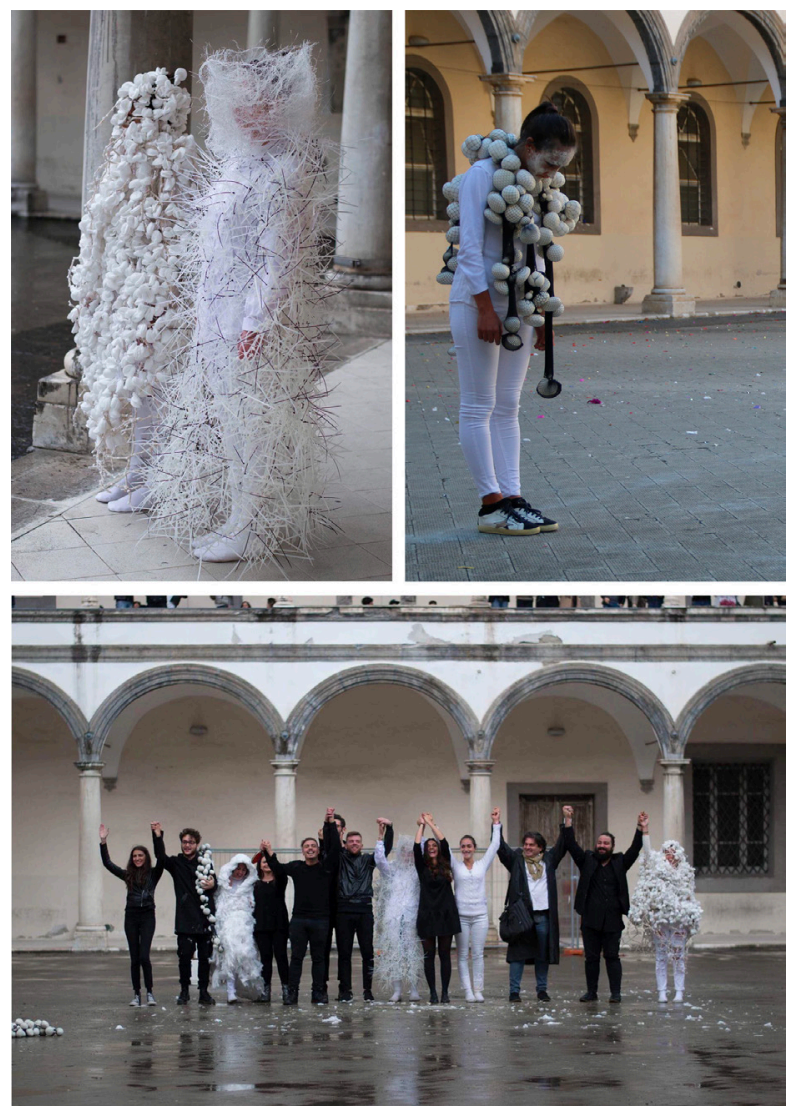
Fig. 3. Quad 2008. 7 LID'A - Laboratorio Internazionale

d'Architettura Scientific, Direction: Laura Thermes. Workshop curator: Carlos Campos. Reggio Calabria and Messina. The characters of the public space. Workshop public space. Workshop by Renato Nicolini. performe occasion two performances were set up, one in Reggi Calabria and one in Messina to emphasise the idea of the 'distance' between the two coasts of the Strait.
The bodies avoid each other and, in that avoidance, one might say, is their only chance of survival. Only in this way is the series allowed to continue and exhaust all the possible combinations.

This is a powerful and unsuspecting metaphor for the contemporary condition that reshapes not only our habits but also our environment, and does so by proposing the "creation of existential bubbles -often in the form of restricted cells- in which we confine our range of action, in which we nevertheless feel we can be safe" [5], in a condition that forces us to renegotiate the proxemic relationship with the other, whose contact we shy away from. There is more. In describing the condition of Quad's characters, Deleuze introduces the image of the exhausted, taking care not to confuse it with that of the tired. The exhausted are much more than the tired: 'the tired has only exhausted the enactment, while the exhausted exhausts everything possible. The tired can no longer realise, but the exhausted can no longer make possible" [Deleuze 2010, p. 9]. And probably that of exhausted is the existential condition closest to what we are living in our unimaginable present time, in our

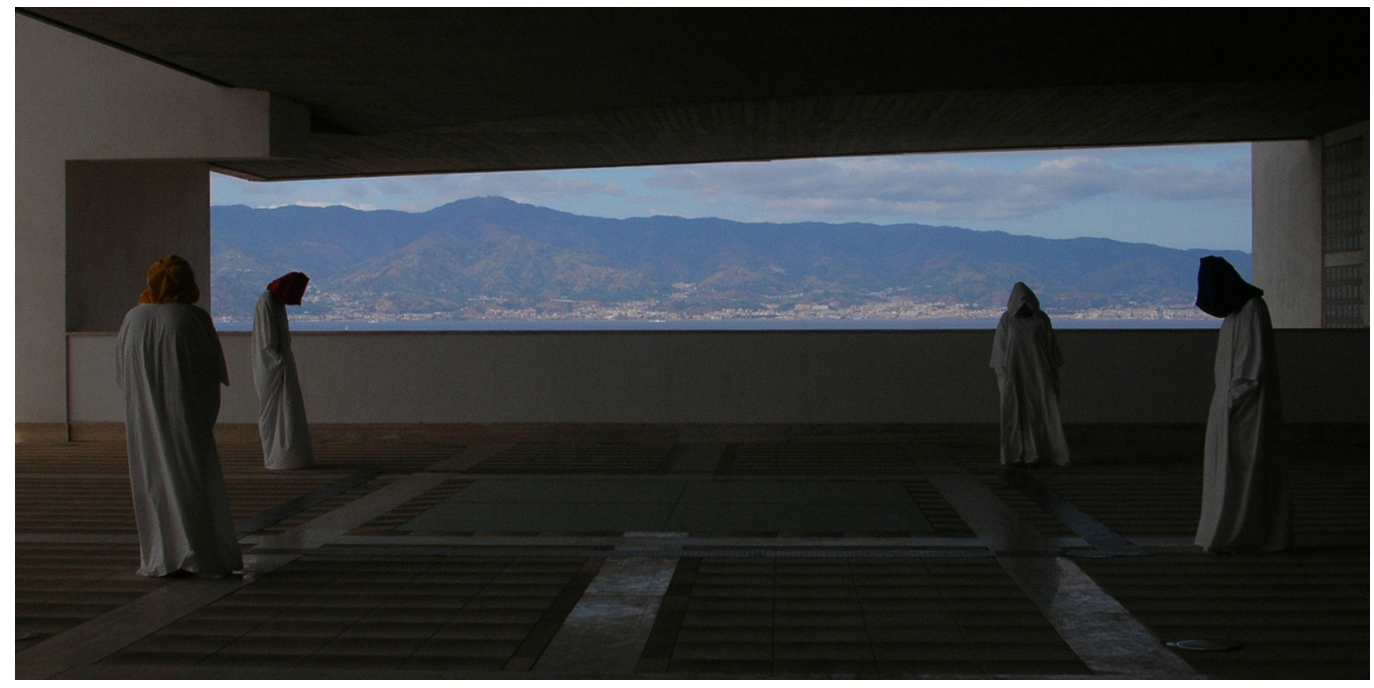

incessant exhaustion not only of the limited space that we are allowed to inhabit, but also of the possibilities of that mental space that we seem to lose with every new deprivation, every new limit imposed at every new mental as well as physical confinement that we experience every day. But it is not only because of this powerful interpretative suggestion that it is interesting for us, today, to look at Quad as a source of inspiration. Quad prompts us to reflect on the modalities of remediation of visual languages, if by remediation we mean the fortunate neologism coined by Bolter and Grusin [6], who intend to describe the new modes of relationship that characterise the interrelation between the various media environments, especially today in a panorama marked by the pervasive presence of digital media. Quad is a work conceived by Beckett for television, and this fact is not marginal. Beckett, in fact, performs a fundamental act of re-mediation of the theatrical language in the new media environment of television. He experiments with the times and stresses its expressive potential with a meticulous attitude aimed at capturing the essence of the medium he uses, at basing expression above all -if not exclusively- on what characterises it "and therefore his writing, just as it had privileged sound in radio plays, so it privileges the image in those for television" [Bertinetti 2002, p. XXVIII], going so far as to completely abolish the verbal element, removing all reference to what we normally associate with the idea of television drama. In Quad, the camera is "high and fixed, outside the closed space and working continuously" [Deleuze 20 I0, p. 37]. It is a single sequence plan, a bird's eye view of the actors in which the action taking place is always the same. Beckett's important lesson on the need to always reflect, but today more than ever, on the continuous process of re-mediation of 
languages and media environments. The obligation of social distancing, imposed in recent months, has subjected a large number of social, cultural, working and educational practices to a digital re-mediation that makes it no longer possible to postpone a reflection on the relationship that has been established between the different media, underlining their strong and continuous interrelationship in a landscape like the contemporary one, marked by the presence of digital technologies. The tension between the tendency towards ubiquity of media experience and the construction of new barriers thus becomes a daily concern that deserves to be investigated [7].

Opening a reflection on these issues requires addressing both the investigation of techniques, media and forms of visual culture. In this sense, the process of re-mediation indicates, precisely, the uninterrupted operation of commentary, reproduction and reciprocal replacement between one medium and another, through which the new incorporates and transforms the previous. This is a condition that, looking at Beckett's experience, has always existed, but which -Bolter and Grusin are right- today assumes a different and greater recurrence and importance. It is part of an entirely new technological horizon, in continuous and rapid metamorphosis, to which the pre-existing means of communication cannot but adapt, taking into account the related risks from a stylistic and aesthetic point of view, i.e. the possible dissolution of the specificities of media languages in the plurality of the audiovisual world. (A.C.).

Fig. 4. Quad 2008. 7 LID'A - Laboratorio Internazionale d'Architettura Scientific, Direction: Laura Thermes. Workshop curator: Carlos Campos. Reggio Calabria and Messina. The characters of the public space.. Photo by Francesco Tosetto.

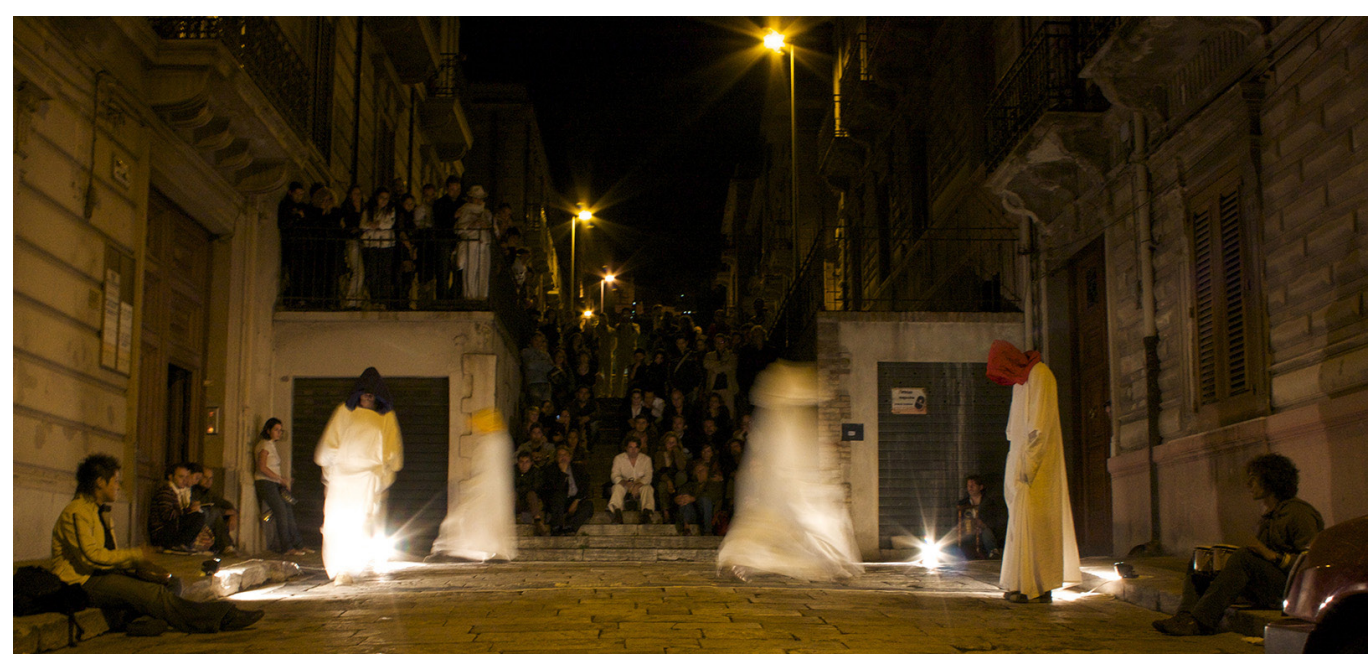

\section{Quad. A wave on the seashore}

Quad was originally a television show. Thus, television is an artifact that emits an image from a fixed point, from a given space, a room, at least at the time when Beckett was thinking of Quad.This means that the original representation of the show did not show a group of actor-dancers alternately traversing the diagonals and sides of a square, while four drummers play synchronously, but its transmission (or reproduction). Beckett uses the television image in the same way as photography, extracting an image from the flow of experience, fixing it and multiplying it at the same time. This is Beckett's first action in relation to the media of television.

Since (W)horoscope, Beckett knows that words are unable to grasp the dynamics of the conscious production of meaning. Thus, the television images will not be able to grasp the different perspectives -and therefore the approximation scales- in which the live performance takes place.

These different perspectives will be lost, as well as the associations, reflections, changes of level and antagonisms that lead consciousness to drift its own flow. Beckett wants to fix 
this flow in works like (W)horoscope, compressing time, while at the same time denouncing that this action is as impossible as necessary. In Quad, the static camera, focused on a bird's eye view of the actors, performs the same action. Once Beckett assumes the media for his representation, he decides to take it to its limits, to those places where experience is re-naturalized.

In Quad, there is no 'original', or the original (both the film and the dancers at the time of performing), has little or no relevance at all. Beckett uses television to apply this concept to his theatre: Just as photography has changed the concept of 'original' (in terms of 'unique, unrepeatable, univocal' that painting, monocopy or deguerrotype had).

When the means destined to produce the 'look' become mechanical, and furthermore, as in the case of photography, unlimitedly reproducible, the concept of 'originality' unfolds, weakens and vanishes. It is no longer the brushstroke of the Flemish painter, which must be imitated by the forger with infinite effort and endless training to the point of having to deeply transform his own being, which gives authenticity to the work.

Photography (and even more so television) contains the artistic - or vital - experience in an interface, connecting it to the world in an unlimited way. In the case of photography, through the serial reproducibility which, combined with the circulation apparatus of newspapers, places it all over the world almost simultaneously. Television is a product of this intertwining of media. Beckett's theater for television is the result of understanding this deformation of action perception on behalf of a systematization of the image that not only appropriates all spaces, but also all gazes. Furthermore, it is unable to stop. If today putting something on the Internet means giving up control over that thing, in the 1980s, broadcasting something on television meant losing control over representation.

Quad is first and foremost, the televised representation of Quad. Only after an editing session, using a particular framing, Quad is installed in the world. Quad is not an Opera, a concert or a ballet, which can be filmed at the moment of its performance, and whose recording evokes that specific moment. Quad works within the complexity of an atemporal world, always detached from its own representation, in view of the constitution of an infinitely reproducible, infinitely 'real' space. By fixing our gaze on that screen without giving us any chance of escape, Beckett forces us to focus on that central point, the E point, the

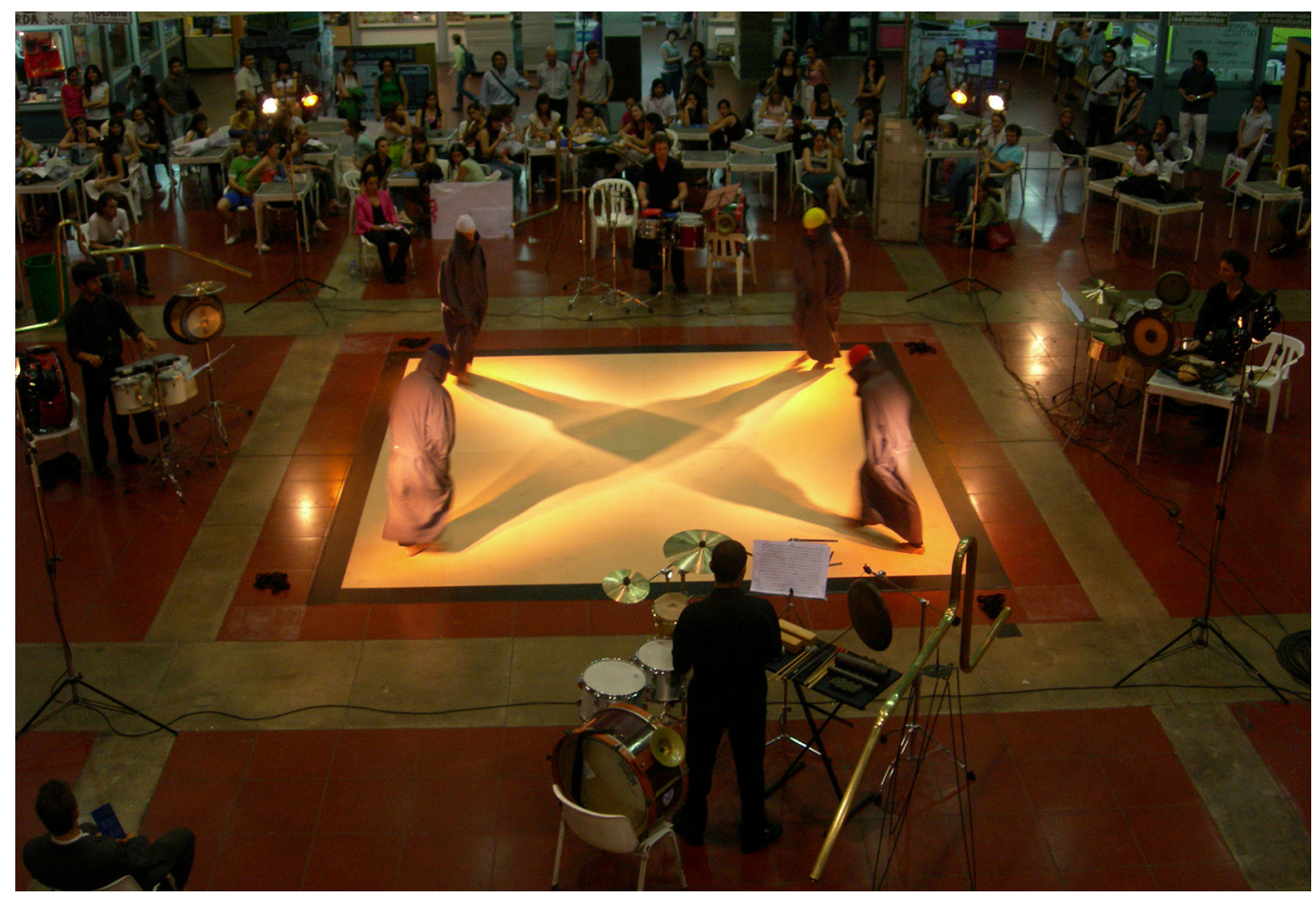


center of the conflict and the engine of the opera's drama. This point works as the eye from the screen. From there, designed for a single eye Quad stares at us. From the moment the square floor, the four actors and their paths become icons, they perform their function, that of producing the effect of keeping us under their gaze. From its arrangement on the screen, Quad hides and reveals, exhibits and separates the characteristics of a representation.(C.C).

Fig. 6. Simulation and fractalisation of Quad. Carlos Campos, Yamila Zynda Aiub. Collaborator: Martín Gromez. The image simulates the process through a digital sumulation, it is possible to insert more 'actors' in the scene: I quad, 4 quads, 16 quads Captures from the original video.
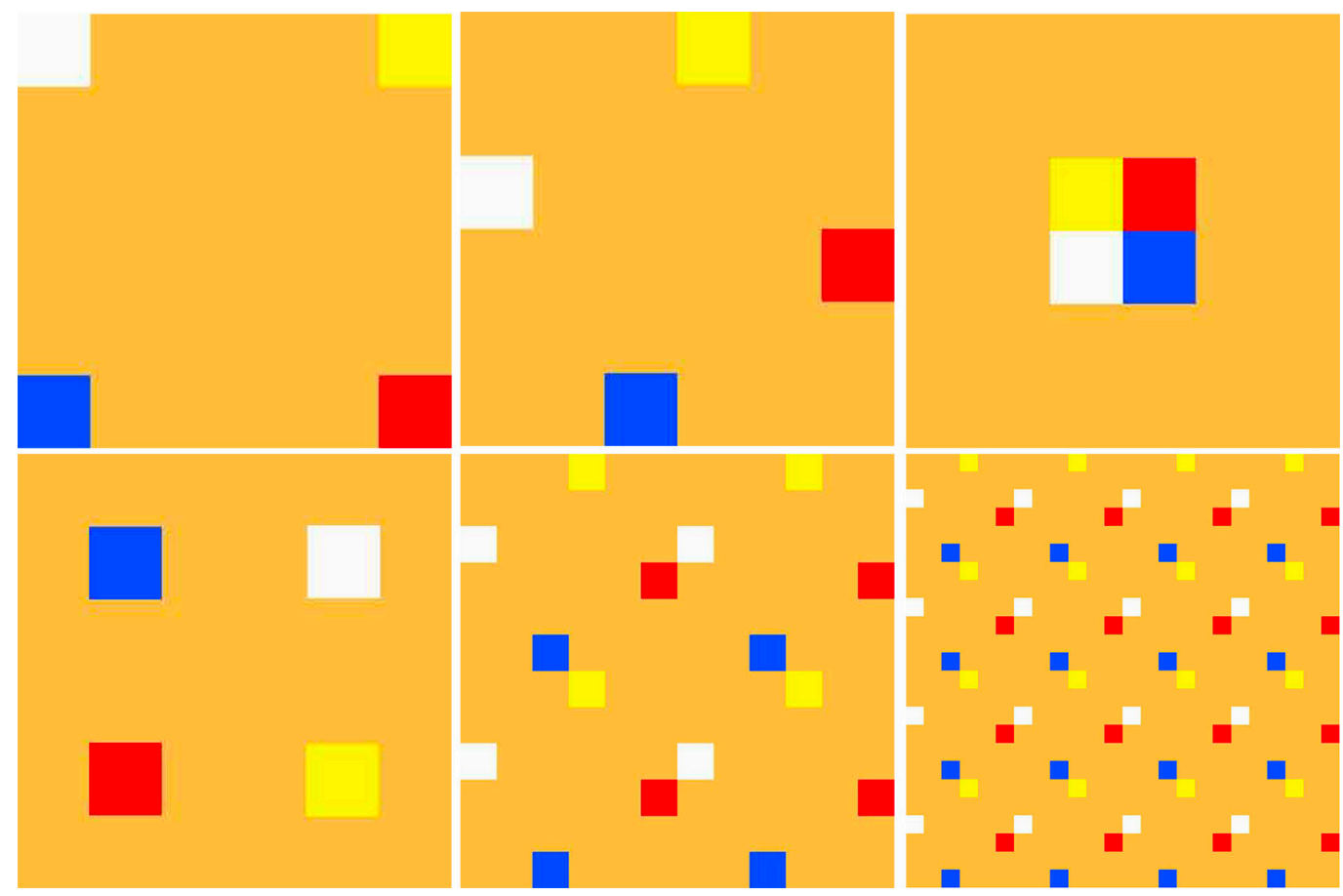

\section{Quad. Simulation and fractalization}

Originally proposed as a rehearsal mechanism for musicians and dancers, simulation is itself a new tool. Within it, Quad begins to exist in an unprecedented new space: fractalization. Quad simulation allows you to instantly perceive something that Beckett has to work hard on the scene: the arrival of the characters from nowhere, and their escape into nowhere. This is so simple in the virtual world. Fractalization allows the number of 'actors' at the center of the representation to be increased in geometric progression, something that, in a staging with real people, would be impossible. Instead of seeing a single square with four actors moving on it, we can put together four stages, with sixteen actors. Or sixteen stages, with sixty-four actors. And so on. As we increase the number of stages and actors, the movement diminishes the perception of its original speed, producing a virtual stop of the performance. To understand this better, imagine an analogous situation. Think of a wave, on the seashore. We perceive its movement from the beach as a cyclical, repetitive and constant murmur. As a continuous set of discontinuous events. On the other hand, if we are swimming inside the wave, we perceive it as a great and thunderous general convulsion, in which the sounds mix, the movement and the event dominate our body, of which we lose all control. Standing now on top of a ravine, we perceive the wave as a gentle ripple that barely whispers. But if we were inside an airplane instead, we would see a white and silent stillness from the window. Thus the 'breaking wave' event not only has multiple conformations depending on our point of view, but from a considerable distance, the back-and-forth motion of the wave literally stops. While we are witnessing the progressive increase of virtual actors in fractal simulation, we are witnessing at the same time various phenomena of an aesthetic and poetic nature. An effect of 'distancing' or distancing from the space in which the work takes place. 
Not only because the squares that replace the actors representing the show become smaller, but also because the attention previously captured by a single group of performers must now be divided into many groups, introducing different levels of motion detection, new generalities, links and singularities. Moreover, maintaining, obviously, the same temporal cadence of the work, (having more actors does not mean that the work has to be performed faster), the relative speed of each Quad must necessarily be reduced. As in many other works by Beckett, the infinite superposition of a poetic expression vehicle (the word, or in the case of Quad, movement), would produce a stop of meaning.

It is necessary to repeat, over and over again, what is not possible to understand. This lesson is useful to us designers today, as it has never been before, because today is the moment when the world has become what these works anticipated. (C.C.).

Fig. 7. Samuel Beckett: Quad I+II (play for TV) photograms from the recording of the first broadcast by a German broadcaster on 8

October 1981. <https:// munyoutube.com/

watch? $=4 Z \mathrm{DRfn} / \mathrm{C}$

q $M>(\operatorname{accessed} 202$

March 20)

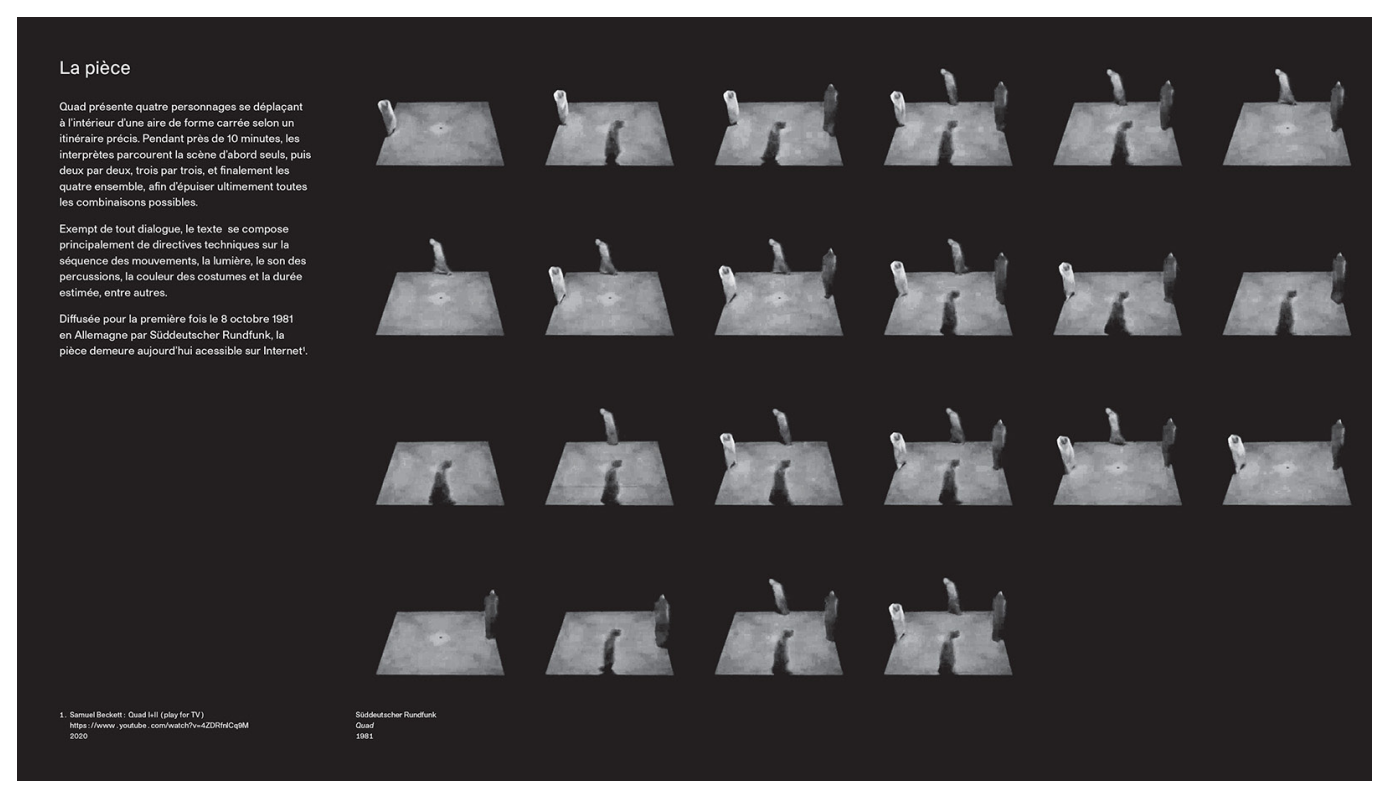

Notes

[I] The performance is the result of the international workshop organised as part of the Visiting Professor activities at the Department of Architecture and Industrial Design of the University of Campania Luigi Vanvitelli by professor Carlos Campos, full professor at the FADU of the University of Buenos Aires. The activities, carried out in collaboration with professors Alessandra Cirafici and Caterina Cristina Fiorentino, were dedicated to the students of the Fashion Design degree course and involved the entire production of the show, including the design of the percussion instruments and the creation of the fabrics for the tunics. The students performed in the Cloister of San Lorenzo on 9 November 2017.

[2] Initially, one figure crosses the path, then another joins in until there are four figures on stage; then, they come out one by one as each one finishes its pattern, leaving only one figure in the space. Gradually, all the possible combinations of players are presented at least once. Each figure describes half the square, tracing the incommensurability of the side and diagonal, making a jerky left turn to avoid the centre. The figures seem to avoid each other, but gradually one realises that they are avoiding the centre, which somehow represents an empty spatial object.

[3] The reference is to the concept of 'device' expressed by Michel Faucault in Dits et écrits II, 1976-1988. On the interpretation of meaning see also Gilles Deleuze, 2007 e Giorgio Agamben, 2006.

[4] The original script foresaw the use of coloured lights to illuminate and underline the different combinations of dancers on the square. In fact, the version that was broadcast on 8 October 1981, directed by Beckett himself, is more essential and suggestive. In addition, an important decision was taken: to follow the original colour film with the sound of the percussion instruments with a replica of the same film, but in black and white and with only the sound of the steps (hence the 'alternative' title of the work: Quadrat I + II). When Beckett first saw the effect of the two versions side by side he exclaimed: "It seems that the second part takes place ten thousand years after the first!". 
[5] On the concept of the existential 'bubble' linked to the condition of contemporary re-mediation of the concept of distance, see F. Casetti, 2020, pp. I06-1 19.

[6] The reference is to Jay David Bolter, Richard Grusin, 2003.

[7] On this subject see Pinotti A., Somaini A., 2016.

\section{References}

Agamben G. (2006). Che cos'è un dispositivo?. Milano: Nottetempo.

Beckett S. (1982). Quad. Londra: Faber\&Faber [prima edizione italiana: Einaudi, 1985; prima messa in scena per la rete televisiva tedesca Suddeutscher Rundfunk, 8 Ottobre 1981].

Bertinetti P. (2002). (a cura di). Samuel Bekett. Teatro.Torino: Giulio Einaudi Editore.

Bolter J. D., Grusin R. (2003). Remediation. Competizione e integrazione tra media vecchi e nuovi. Milano: Guerini e Associati, Milano.

Cascetta A. M. (2000). Il tragico e l'umorismo. Studio sulla drammaturgia di Samuel Bekett. Firenze: Editoriale Le Lettere.

Casetti F. (2020). Close-up-ness. Masks, Screens, and Cellsl. In M.Treleani, F. Zucconi (a cura di). IMG journal, Issue 03 Remediating distances, pp. 106-119.

Deleuze G. (2007). Che cos'è un dispositivo?. Napoli: Cronopio.

Deleuze G. (20 I0). L'esausto. Napoli: Edizione Cronopio (titolo originale L'epuisé. Paris: Les Edition del Minuit, 1992).

Pinotti A., Somaini A. (2016). Cultura visuale. Immagini, sguardi, media, dispositivi. Torino: Einaudi.

Authors

Alessandra Cirafici, Università degli Studi della della Campania "Luigi Vanvitelli", alessandra.cirafici@unicampania.it Carlos Campos, Universidad de Buenos Aires, ccamposarq@gmail.com

To cite this chapter. Cirafici Alessandra, Campos Carlos (2021). L'occhio immobile di Quad che ferma il mondo/Quad's motionless gaze that stops the world. In Arena A., Arena M., Mediati D., Raffa P. (a cura di). Connettere. Un disegno per annodare e tessere. Linguaggi Distanze Tecnologie. Atti del $42^{\circ}$ Convegno Internazionale dei Docenti delle Discipline della Rappresentazione/Connecting. Drawing for weaving relationship. Languages Distances Technologies. Proceedings of the $42^{\text {th }}$ International Conference of Representation Disciplines Teachers. Milano: FrancoAngeli, pp. $1507-1524$. 